\title{
PENINGKATAN PENGETAHUAN PENGELOLAAN WISATA DI PULAU LOMBOK BERBASIS MEDIA SOSIAL BAGI SISWA KABUPATEN LOMBOK BARAT
}

\author{
SULAEMAN, ZINNU RAIN, MA'RUF AL GIFARI, MUHAMAD SUHARDI
}

Universitas Pendidikan Mandalika(UNDIKMA)

Coresponding email : yazid.emen@gmail.com

\begin{abstract}
Social media is a communication and interaction forum used by millennials to interact and share information with one another. The potential of social media as a media for tourism promotion is very large, but it is still not optimally utilized for productive activities, including students of Madrasah Aliyah Al Madani, West Lombok Regency due to the lack of knowledge and skills of madrasah students in the use of social media they have. This training aims to improve the knowledge and creativity skills of MA Al Madani students in utilizing social media as a promotional media in tourism management, especially in program promotion activities and tourism media. The stages of this service activity process begin with observing the potential of schools, followed by discussion activities and formulating the theme of training activities in accordance with school plans and programs, then carrying out training activities according to the agreed theme until post-training evaluation activities take place. The training activities were guided by expert trainers, it was found that through this training students could develop their skills in the use of various social media as a promotional platform in developing and managing tourism programs in Lombok Nusa Tenggara. The evaluation process, by monitoring and examining the trainees' social media after one week of training, shows that the program has been successfully developed and utilized by MA Al Madani students, West Lombok Regency, West Nusa Tenggara.
\end{abstract}

Keywords: Social Media, Training, Tourism Management

\begin{abstract}
ABSTRAK
Media sosial merupakan wadah komunikasi dan interaksi yang digunakan oleh kalangan milenial untuk berinteraksi dan berbagi informasi antar satu dengan lainnya. Potensi media sosial sebagai media promosi wisata sangatlah besar, akan tetapi masih belum optimal dimanfaatkan untuk kegiatan produktif termasuk oleh siswa Madrasah Aliyah Al Madani Kabupaten Lombok Barat disebabkan karena masih kurangnya pengetahuan dan keterampilan siswa madrasah yang ada dalam pemanfaatan media sosial yang dimiliki. Pelatihan ini bertujuan untuk meningkatkan skill pengetahuan dan kreativitas siswa MA Al Madani dalam memanfaatkan media social sebagai media promosi dalam manajemen wisata, terutama dalam kegiatan promosi program dan media wisata. Adapun tahapan proses kegiatan pengabdian ini dimulai dengan kegiatan obserasi potensi sekolah, diikuti dengan kegiatan diskusi dan perumusan tema kegiatan pelatihan yang sesuai dengan rencana dan program sekolah, selanjutnya melaksanakan kegiatan pelatihan sesuai tema yang telah disepakati hingga kegiatan evaluasi pasca pelatihan berlangsung. Kegiatan pelatihan dipandu oleh pelatih ahli, didapati bahwa melalui pelatihan ini para murid dapat mengembangkan skill mereka dalam pemanfaatan berbagai media social sebagai wadah promosi dalam mengembangkan dan mengelola program wisata yang ada di Lombok Nusa Tenggara. Proses evaluasi, dengan memantau dan menelah media sosial peserta pelatihan setelah satu minggu pelatihan, menunjukkan bahwa program tersebut telah berhasil dikembangkan dan dimanfaatkan oleh para murid MA Al Madani Kabupaten Lombok Barat Nusa Tenggara Barat.
\end{abstract}

Kata Kunci : Media Sosial, Pelatihan, Manajemen wisata

\section{PENDAHULUAN}

Indonesia memiliki potensi wisata yang beraneka ragam, baik daroi segi alam berupa wisata berbasis alam, budaya dan manusia.semua potensi wisata yang ada, jika dikelola dengan 
baik dan tepat akan mampu mendatangkan devisa, serta dapat menyentuh kesejahteraan masyarakat didaerahPariwisata merupakan, (Foulkner, 2003). Salah satu daerah yang memiliki potensi pariwisata menarik untuk terus dikembangkan adalah Pulau Lombok Nusa Tenggara barat.

Nusa Tenggara Barat adalah salah satu tujuan utama wisatawan lokal maupun mancanegara di Indonesia, terlebih lagi dengan ditetapkannya sebagai salah satu kawasan destinasi wisata prioritas dalam rangka pertumbuhan pariwisata nasional berdasarkan Peraturan Presiden Republik Indonesia Nomor 93 Tahun 2017 dengan adanya pembangunan Kawasan Ekonomi Khusus (KEK) Mandalika di Pantai Kuta Kabupaten Lombok Tengah. selain adanya Kawasan KEK ini, pulau Lombok juga memeiliki berbagai destinasi wisata lainnya yang sangat menarik untuk dikunjungi, diantaranya pantai Senggigi di Kabupaten Lombok Barat, Kawasan Wisata Gili Matra (Gili Trawangan, Gili Meno dan Gili Air) di Kabupaten Lombok Utara, kuliner Ayam Taliwang, serta destinasi wisata lainnya.

Salah satu upaya yang dapat dijalankan untuk mendukung keberhasilan pariwisata di pulau Lombok dan Nusa Tenggara Barat secara umum adalah dengan melibatkan semua kalangan termasuk masyarakat khusunya remaja dan milenial dalam kegiatan promosi pariwisata yang ada di Pulau Lombok. Partisipasi remaja disini bias dilakukan dengan du acara, yang pertama dengan melibatkan remaja untuk ikut dalam mempromosikan pariwisata melalui media sosialnya masing-masing sebagai langkahg awal yang efektif, serta cara kedua adalah dengan memberikan penyuluhan dan pelatihan mengenai potensi media sosial untuk mempromosikan daerah wisatanya masing masing.

Sebagai bagian dari pemangku kepentingan dalam pengelolaan pariwisata, remaja dan milenial khususnya Siswa Madrasah Aliyah Al Madani Kabupaten Lombok Barat, pada umumnya sudah melek dengan media sosial, namun terkadang dalam menggunakannya untuk kegiatan promosi destinasi wisata yang ada di daerah ini masih harus dipoles lagi supaya mereka memiliki skill dan lebih terampil dalam menentukan objek wisata, tulisan narasi yang menarik dan menyentuh emosi, menciptakan trik fotografi yang lebih mengesankan bagi kalangan pembacanya.

Berdasakan permasalahan awal dari hasil pengamatan dan diskusi awal dengan kepala sekolah yang ada, terkait dengan kemampuan pemanfatan media sosial bagi siswa Madrasah Al Madani, maka diperlukan suatu upaya peningkatan skill pengetahuan dan keterampilan berkomunikasi dalam pengelolaan wisata berbasis teknologi informasi berupa media sosial di kalangan siswa MA Al Madani Kabuipaten Lombok Barat Nusa Tenggara Barat. Karena dengan adanya keterampilan dalam menggunakan media sosial ini dapat memviralkan konten, (Wiwiek, 2016).

Media sosial merupakan suatu media sebagai wahana bagi para penggunanya dapat berkreasi, berpartisipasi, berbagi, dan membuat konten konten berupa blog, wa, Instagram, telegram, twiter, facebook dan sebaginya dengan ciri khas dan system yang berbeda beda diantara jejaring sosial yang satu dengan lainnya, (Boyd dan Ellison:2007). Media sosial ini merupakan salah satu alat berinteraksi yang cepat dan praktis bagi para penggunanya dan bertukar informasi yang dapat digunakan oleh siswa yang ada dalam menjalankan aktivitas pariwisata. Dengan kata lain Media sosial dalam perkembangan nya sangat memudahkan semua orang untuk berkomunikasi, berpartisipasi, saling berbagi, dan membentuk suatu jaringan online, sehingga dapat menyebarluaskan konten mereka sendiri (Zarella: 2010).

Adanya begitu besar manfaat dari Media sosial menjadi media yang dapat dipergunakan dalam pengembangan dan pengelolaan merupakan alat untuk meningkatkan kemampuan pengguna untuk berbagi (to share), bekerja sama (to co-operate) di antara pengguna dan melakukan tindakan secara kolektif yang semuanya berada di luar kerangka institusional meupun organisasi",serta manfaat yang begitu besar, (Nasrullah, 2018).

Lebih lanjut Nasrullah (2018) menjelaskan bahwa media sosial memiliki beberapa karakteristik,sebagai jaringan dengan membentuk jaringan diantara penggunanya, sebagai media informasi, arsip sehingga dapat diakses kapanpun melalui perangkat apapun, media 
interaksi, wahana simulasi social, konten oleh pengguna, dan penyebaran atau sharing. Media social ini merupakan media baru yang dapat dipergunakan dan dimanfaatkan dalam pengembangan pariwisata karena media ini memiliki interktivitas yang sangat tinggi (Flew, 2002). Pada umumnya jejaring sosial yang ada,memiliki kapasitas untuk dapat melakukan pertemanan dengan semua orang dibelahan dunia manapun dan dapat menjalankan komunikasi satu dengan lainnya (Madcoms, 2010), selain itu jejaring sosial ini merupakan media bertukar informasi, berbagi foto, video dan lainnya. Adapun foto foto yang diunggah dapat dari berbagai karakter gambar baik berupa pemandangan, foto keluarga, wahana dan media wisata serta foto lainnya (Agustina, 2016).

Dalam komunikasi pemasaran sendiri media sosial termasuk dalam interractive markerting, karena media sosial memungkinkan terjadinya arus informasi timbal balik yang memungkinkan pengguna dapat berpartisipasi dan memodifikasi bentuk dan isi informasi pada saat itu juga (real time). Sedangkan partisipasi adalah berasal dari bahasa Inggris participate yang artinya mengikutsertakan, ikut mengambil bagian (Willie Wijaya:2004). Fasli Djalal dan Dedi Supriadi (2001) juga mengemukakan partisipasi dapat juga berarti bahwa pembuat keputusan menyarankan kelompok atau masyarakat ikut terlibat dalam bentuk penyampaian saran dan pendapat, barang, keterampilan, bahan dan jasa. Partisipasi juga berarti bahwa kelompok mengenal masalah mereka sendiri, mengkaji pilihan mereka, membuat keputusan, dan memecahkan masalahnya.

Perkembangan media sosial membuat kinerja menjadi lebih cepat, tepat, akurat sehingga dapat meningkatkan produktivitas yang dihasilkan., selain itu media sosial merupakan alat promosi bisnis yang efektif karena dapat diakses oleh siapa saja, sehingga jaringan promosi bisa lebih luas, selain itu media sosial dapat dijadikan alat promosi yang murah serta mudah dilakukan oleh setiap kalangan (Muttaqien dan Wardana, 2020). Promosi merupakan kesatuan elemen variable pemasaran yang bertujuan untuk menyampaikan informasi, membujuk, dan mengingatkan konsumen (wisatawan) tentang suatu produk atau jasa. Promosi sangat penting untuk dilakukan dalam usaha untuk memasarkan suatu produk atau jasa dengan rencana dan konsep yang matang sehingga dapat menarik dan bahkan membeli produk atau jasa tersebut. Rancangan promosi harus disusun semenarik mungkin dan penyampaian informasi harus mudah dipahami oleh calon konsumen atau wisatawan (Wiro, 2018).

Promosi dan pemasaran merupakan langkah yang harus dilakukan dalam pengelolaan usaha wisata baik itu skala kecil maupun skala besar. Idealnya, adanya promosi wisata akan semakin memperluas jaringan persebaran atau target konsumen (wisatawan), sehingga akan semakin banyak calon wisatawan yang mengetahui suatu destinasi wisata, terlepas dari metode dan media promosi yang digunakan. Karena kurangnya promosi terhadap suatu obyek wisata merupakan salah satu penghambat perkembangan dari obyek wisata tersebut, (Wilopo dan Hakim, 2017).

Menilik dari potensi yang dimiliki oleh siswa yang ada di MA Al Madani belum termanfaatkan dengan maksimal, maka kegiatan pelatihan peningkatan pengetahuan dan skill pemanfaatan media social sebagai wadah promosi dilaksanakan. Pada dasarnya media sosial menjadi bagian yang sangat diperlukan oleh pemasaran bagi banyak perusahaan termasuk sekolah dan skill individu dan merupakan salah satu cara terbaik untuk menjangkau pelanggan dan klien. Media sosial sperti blog, facebook, twitter, dan youtube memiliki sejumlah manfaat bagi perusahaan dan lebih cepat dari media konvensional seperti media cetak dan iklan TV, brosur dan selebaran. Untuk membangun pengetahuan dan meningkatkan skill siswa MA Al Madani Kabupaten Lombok Barat, sehingga PKM Pelatihan manajemen pengelolaan wisata berbasis media sosial ini penting untuk dilakukan sebagai bagian dari pelatihan media promosi, Dengan adanya pelatihan ini, diharapkan dapat menjadi nilai tambah bagi siswa dan menjadi skill tambahan bagi lulusan MA Al Madani meskipun sekolah ini sekolah berbasis pesantren yang terfokus pada pendidikan agama. Sehingga tujuan dari pelatihan ini dapat tercapai yaitu tersedianya SDM bidang promosi bagi MA Al Madani Kabupaten Lombok Barat yang dapat mengelola dan menjalankan kegiatan promosi sekolah dengan memanfaat media social dengan 
berbagai jenisnya serta meningkatnya skill siswa dalam memanfaatkan media social yang dimiliki kearah yang lebih produktif dan bermanfaat untuk pribadi, sekolah dan lingkungan sekitanya

\section{Permasalahan Mitra}

Berdasarkan analisis situasi dan wawancara guru serta perwakilan siswa, Permasalahan yang dihadapi oleh siswa MA Al Madani terkait dengan pemanfaatan media sosial sebagai media promosi wisata adalah sebagai berikut :

1. Guru belum berpartisipasi aktif dalam membimbing siswa dan mengarahkan siswa dalam pemanfaatan media social untuk pengembangan manajemen wisata

2. Kurangnya kreativitas atau keahlian siswa dalam memanfaatkan dan menghasilkan konten Media social yang inovatif untuk pengembangan wisata

3. Tidak pernahnya pelatihan peningkatan kreatifitas yang melibatkan siswa MA A Madani

Dengan melihat permasalah tersebut, maka sangat perlu diupayakan pemecahan permasalahan yang dihadapi siswa sekoah Madrasah Aliyah Al Madani Kabupaten Lombok Barat. Berdasarkan kesepakatan dengan mitra, maka permasalahan utama yang segera diselesaikan adalah menjelaskan secara detail bagaimana tahapan peningkatan kapasitas skill siswa terkait dengan manajemen wisata berbasis media sosial serta pemanfaatan media sosial sebagai alat dan media dalam kegiatan promosi wisata.

\section{METODE PENGABDIAN KEPADA MASYARAKAT}

Kegiatan ini adalah kegiatan Pengabdian Masyarakat yang dilakukan oleh dosen Universitas Pendidikan Mandalika bekerjasama dengan Madrasah Aliyah Al Madani sebagai lokasi pengabdian. Adanya pemanfaatan media social yang dimiliki oleh siswa masih sebatas pemanfaatan sebagai media bertukar informasi antar sesame dan belum termanfaatkan untuk kegiatan yang lebih produktif dan bermanfaat terutama untuk kegiatan promosi menjadi dasar dan titik temu kegiatan pengabdian ini dilaksanakan di MA Al Madani Kabupaten Lombok Barat.

\section{TAHAPAN KEGIATAN}

Berdasarkan permasalahan yang dihadapi oleh pihak sekolah dan siswa yang ada adalah masih kurang nya pemahaman siswa dalam pemanfaatan media social yang dimiliki , maka metode kegiatan yang pertama kali dilakukan adalah ceramah dengan memberikan materi tentang pemanfaatan media social, dan manajemen promosi, serta manajemen pariwisata serta diskusi tanya jawab. Kemudian untuk lebih meningkatkan kemampuan pengetahuan tentang pemanfaatan media sosial dilakukan dengan pendampingan membuat konten promosi sederhana, sehingga peserta dapat membuat media promosi, baik untuk sekolah maupun wisata. Dan selanjutnya yang terakhir adalah monitoring an evaluasi kegiatan. Adapun tahapan pelaksanaan kegiatan pengabdian kepada masyarakat ini dijalankan dengan beberapa tahapan, sebagaimana disajikan pada diagram berikut : 


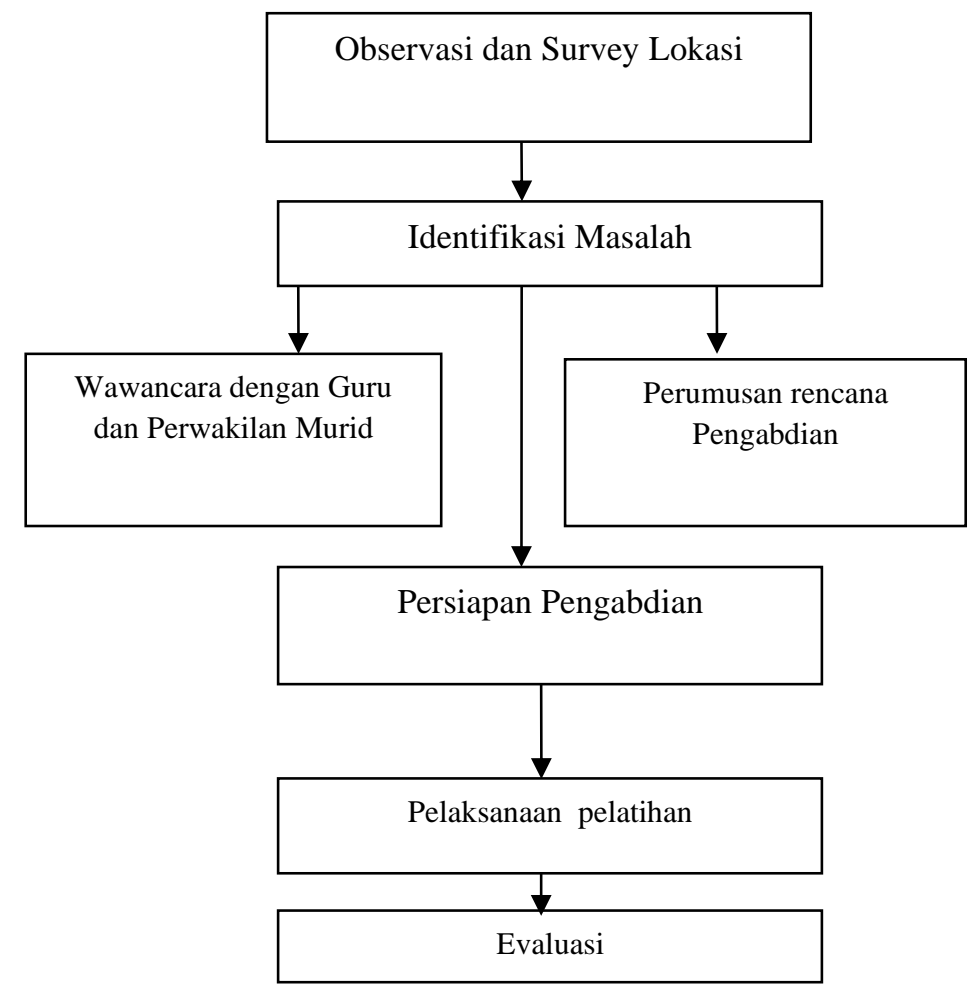

Gambar 1. Diagram Pelaksanaan pelatihan

Adapun tahapan kegiatan pelaksanaan pengabdian ini, sebagaimana disajikan pada diagram dilaksanakan dengan tahapan berikut :

1) Observasi dan Survey lokasi

Kegiatan Observasi dan survey bertujuan untuk menjalin komunikasi dengan calon mitra terkait rencana pengabdian yang akan dijalankan di lokasi mitra dan membangun kerjasama dengan mitra.

2) Identifikasi masalah

Identifikasi masalah berujuan untuk mengetahui masalah yang dihadapi oleh mitra dalam hal ini Madrasah Aliyah Al Madani Kabupaten Lombok Barat

3) Persiapan

Persiapan bentuk pelatihan sesuai dengan hasil identifikasi masalah. Tujuannya agar pelatihan yang diberikan tepat dan sesuai dengan masalah yang dihadapi sekolah

4) Pelaksanaan

Ceramah dan diskusi dengan tema pemanfaatan media social sebagai media promosi . Tujuannya adalah untuk meningkatkan pengetahuan peserta terhadap Pemanfaatan media sosial sesuai dengan kebutuhan dan masalah yang dialami.

5) Evaluasi

Monitoring dan evaluasi pelatihan, yaitu melihat dampak kegiatan pelatihan bagi peserta. Tujuannya adalah untuk melihat dampak pelatihan pemanfaatan media social sebagai media promosi terhadap masalah yang dihadapi oleh peserta. Secara detail adalah dalam memanfaatkan media sosial dan mengetahui sejauh mana keberhasilan pelatihan dalam mengatasi masalah yang dihadapi. 


\section{HASIL DAN PEMBAHASAN}

Untuk mencapai tujuan pelaksanaan kegiatan Pengabdian kepada Masyarakat, ada 5 (lima) tahapan yang dilakukan dalam kegiatan ini, yaitu:

\section{Observasi Mitra}

Kegiatan observasi dan survey adalah langkah awal untuk rencana pengabdian yang sudah disepakati dengan tim, untuk di komunikasikan dengan mitra, observasi ini menentukan apakah rencana pengabdian dapat terlaksana sesaui dengan renacna awal ataukah ada sedikit modifikasi bentuk dan tema yang akan dilaksanakan sesuai dengan kondisi real calon mitra yang dituju, dalam hal ini yang menjadi mitra pengabdian adalah Madrasah Aliyah Al Madani.

\section{Identifikasi Masalah}

Sebagaimana diketahui, bahwa tujuan kegiatan ini adalah untuk mengetahui masalah yang dihadapi oleh calon mitra, dalam hal ini yang menjadi mitra adalah Madrasah Aliyah Al Madani Kabupaten Lombok Barat. Pelaksanaan kegiatan identifikasi ini dilakukan dengan langsung dating berkunjung ke sekolah untuk mmelakukan wawancara dan bertanya langsung kepada pengelola (guru) dan perwakilan murid terkait masalah yang dihadapi. Dengan komunikasi yang baik pihak guru dan perwakilan murid dapat terbuka menjelaskan masalah yang dihadapi dalam mengembangkan sekolah dan peningkatan skill tambahan bagi murid nya. Berdasarkan hasil identifikasi masalah yang dihadapai oleh sekolah adalah minimnya pengetahuan siswa dalam pemanfaatan media sosial bagi kegiatan promosi kea arah yang lebih produktif bagi siswa yang ada terutama dalam pengembangan potensi NTB yang sangat terkenal dengan wisatanya. Pemanfaatan media social bagi siswa yang ada, masih terfokus untuk kegiatan dan aktifitas pribadi saja, belum ada inovasi promosi bagi sekolah dan belum ada inovasi tambahan dalam penggunaan media social oleh pelajar yang ada untuk kegaiatan yang lebih bermanfaat dan produktif. Berdasarkan hasil identifikasi masalah ini, maka diketahui bahwa masalah yang dihadapi oleh sekolah dan menjadi prioritas pengabdian adalah terhadap pemahaman pemanfaatan media social sebagai media promosi. Hasil dari identifikasi masalah ini yang kemudian dilakukan tindak lanjut untuk mempersiapkan bentuk pelatihan bagi peserta yang ada.

\section{Persiapan}

Persiapan bentuk pelatihan disesuaikan dengan hasil identifikasi masalah yang dihadapi mitra agar pelatihan yang diberikan tepat dan sesuai dengan masalah yang dihadapi. Berdasarkan hasil idenfikasi masalah tersebut di atas, maka bentuk pelatihan yang dipersiapkan, yaitu: 1) Ceramah tentang manajemen promosi, media social dan pemanfaatannya dalamm bidang promosi serta dasar dan manajemen pariwisata, yang dilanjutkan dengan diskusi dan tanya jawab. 2) Pendampingan dalam pelatihan membuat konten promosi untuk promosi wisata. 3) Monitoring dan evaluasi terhadap peserta pelatihan. Dalam persiapan pelatihan ini, semua yang dibutuhkan dalam pelatihan disiapkan baik materi dan modul ceramah dan diskusi, bahkan perlengkapan yang dibutuhkan dalam ceramah dan pendampingan dan monitoring dan evaluasi.

\section{Pelaksanaan}

Ceramah dan diskusi tentang pemanfaatan media social sebagai media promosi bertujuan untuk meningkatkan pengetahuan peserta tentang pemanfaatan media social bagi media promosi bidang pariwisata. Dalam praktiknya, kegiatan ceramah ini dilakukan Sekolah MA Al Madani,sehingga peserta dalam hal ini murid yang ikut dalam kegiatan pelatihan lebih leluasa berdiskusi dan bertanya seperti kegiatan belajar pada umumnya.

Saat materi ceramah disampaikan, peserta sangat antusias mendengarkan dan mengikuti penyampaian materi dengan baik. Pada saat kegiatan diskusi, mereka tidak ragu-ragu bertanya tentang pemanfaatan media social dalam kegiatan promosi. Secara umum, dalam kegiatan ini 
diberikan materi tentang manajemen promosi, media social dan pemanfaatannya dalamm bidang promosi serta dasar dan manajemen pariwisata, sehingga meningkatkan pengetahuan mereka tentang konsep media social, manajemen promosi dan pariwisata. Aktifitas saat kegiatan penyampaian materi dan diskusi pada Gambar 1 di bawah ini :

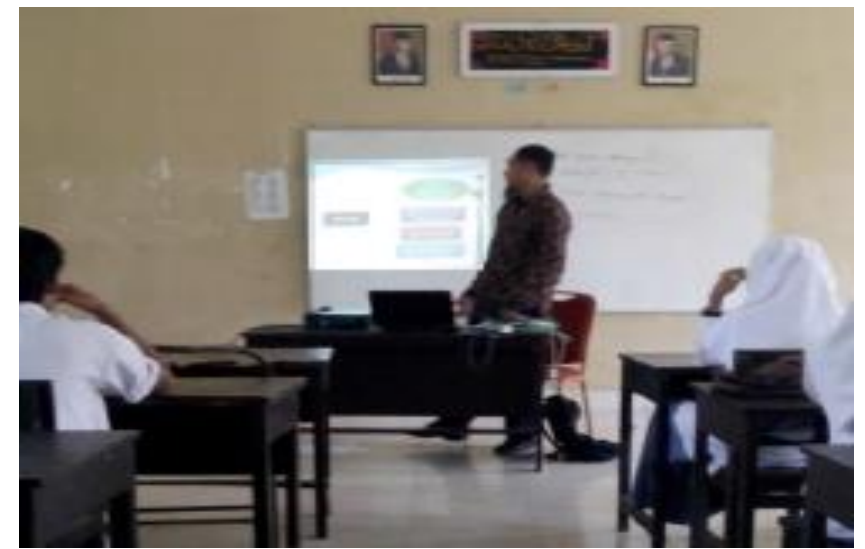

Gambar 1. Peserta menyimak penyampaian materi pelatihan dan kegiatan Tanya jawab

Pada gambar diatas terlihat bahwa para peserta sangat antusias mengikuti kegiatan pelatihan atau penyampaian materi yang diberikan oleh tim pengabdi, sehingga peserta benar benar dapat mengambil manfaat pengetahuan yang diberikan. Adapun materi yang diberikan disajikan dengan media laptop,layar dan proyektor (Gambar 2). Untuk mengantisipasi kemungkinan muncul kebosanan pada peserta, pengabdi menyampaikan materi tidak terfokus hanya dalam bentuk narasi tetapi dalam bentuk audio visual, dengan harapan materi yang disampaikan dapat lebih mudah difahami dan dimengerti oleh seluruh peserta, sehingga semangat dan antusias peserta tetap terjaga selama sesi pemberian materi. Di akhir sesi, peserta pun aktif terlibat dalam diskusi dan tanya jawab (Gambar 3).
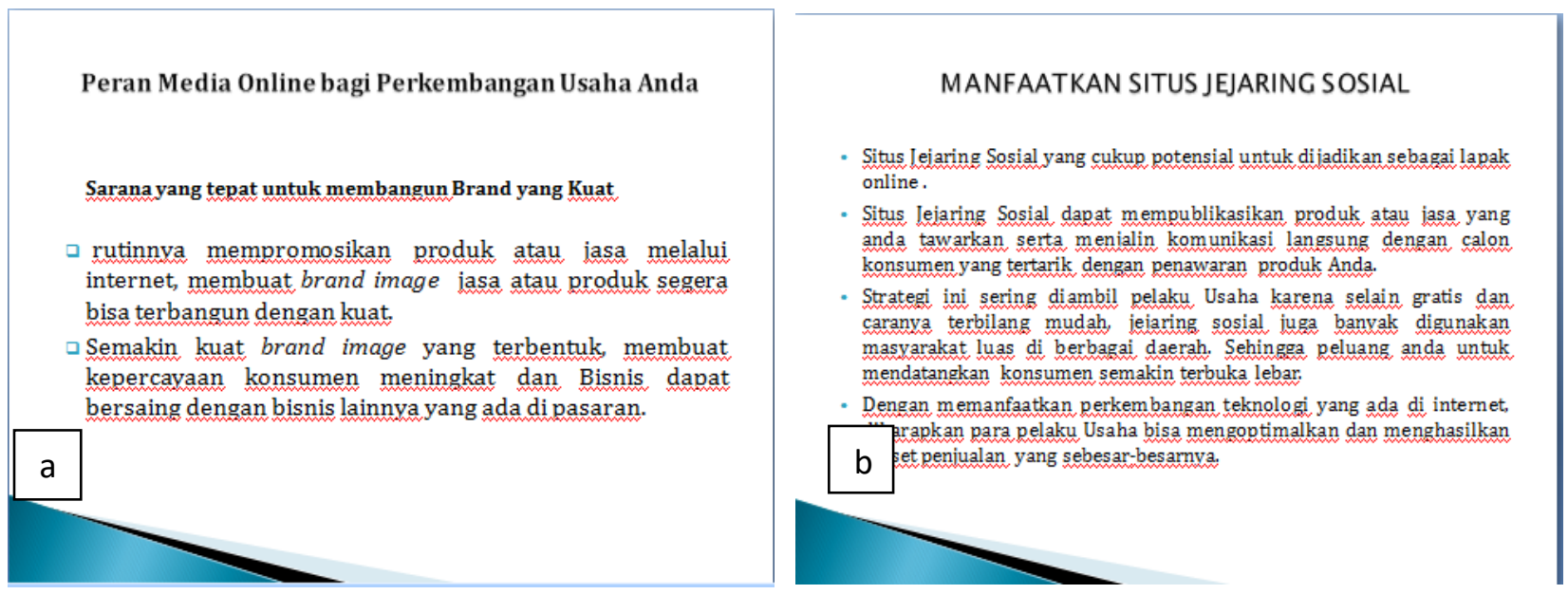

Gambar 2. Beberapa contoh materi yang disampaikan kepada peserta.

a) Peran umum media social bagi usaha;

b) Manfaat Situs Jejaring Social

Adapun kegiatan tambahan yang diberikan dalam pelatihan ini selain ceramah dan diskusi adalah pendampingan dan pengarahan bagi setiap peserta pelatihan dalam membuat dan menyusun konten promosi sesuai dengan tema yang diberikan dan diinginkan, terkait dengan promosi media dan wahana wisata. Hasil dari kegiatan ceramah dan diskusi ini adalah meningkatnya pengetahuan dan skill peserta dala pemamnfaatan media social untuk kegiatan promosi dan meningkatnya pengetahuan peserta terkait dengan manajemen promosi dan manajemen pariwisata. Sehingga peserta pelatihan dapat dan mampu berinovasi dalam 
memanfaatkan akun media social yang dimiliki untuk kegiatan yang lebih bermanfat untuk segala kalangan.

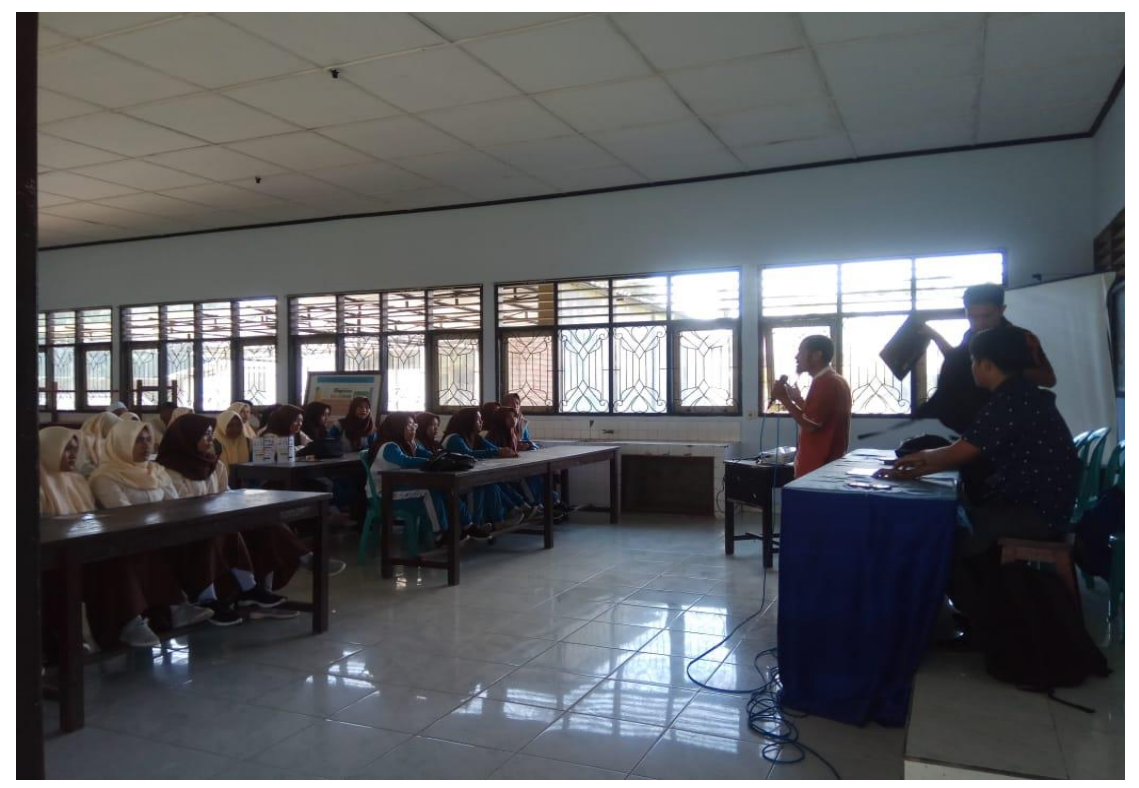

Gambar 3. Sesi Kegiatan diskusi setelah penyampaian materi

Dalam pelaksnaan pelatihan dapat diambil beberapa poin hasil yang didapatkan yaitu : 1) pemahaman peserta menjadi meningkat terkait dengan konsep promosi, manajemen pengelolan wisata, serta dapat mempraktekkan cara membuat tulisan narasi yang menarik dan menyentuh emosi, menciptakan trik fotografi yang lebih mengesankan sebagai bahan promosi yang di share melalui akun media sosial masing masing peserta, 2) Peserta tidak hanya mengetahui manfaat media sosial sebagai wadah promosi wisata, tetapi juga dibekali dengan keterampilan memanaj media sosial yang dimiliki, sehingga kesannya lebih menarik, dan mudah diingat dan 3) Cara penyampaian yang menarik, inovatif dan kreatif sangat mempengaruhi antusiame peserta dalam kegiatan pelatihan dan berdasarkan hasil evaluasi, peserta pun merasa lebih mudah dalam menerima materi pelatihan. Berikut disajikan beberapa contoh unggahan dari peserta dalam mempromosikan obyek wisata di Lombok dengan akun media social peserta masing masing (Gambar 4).
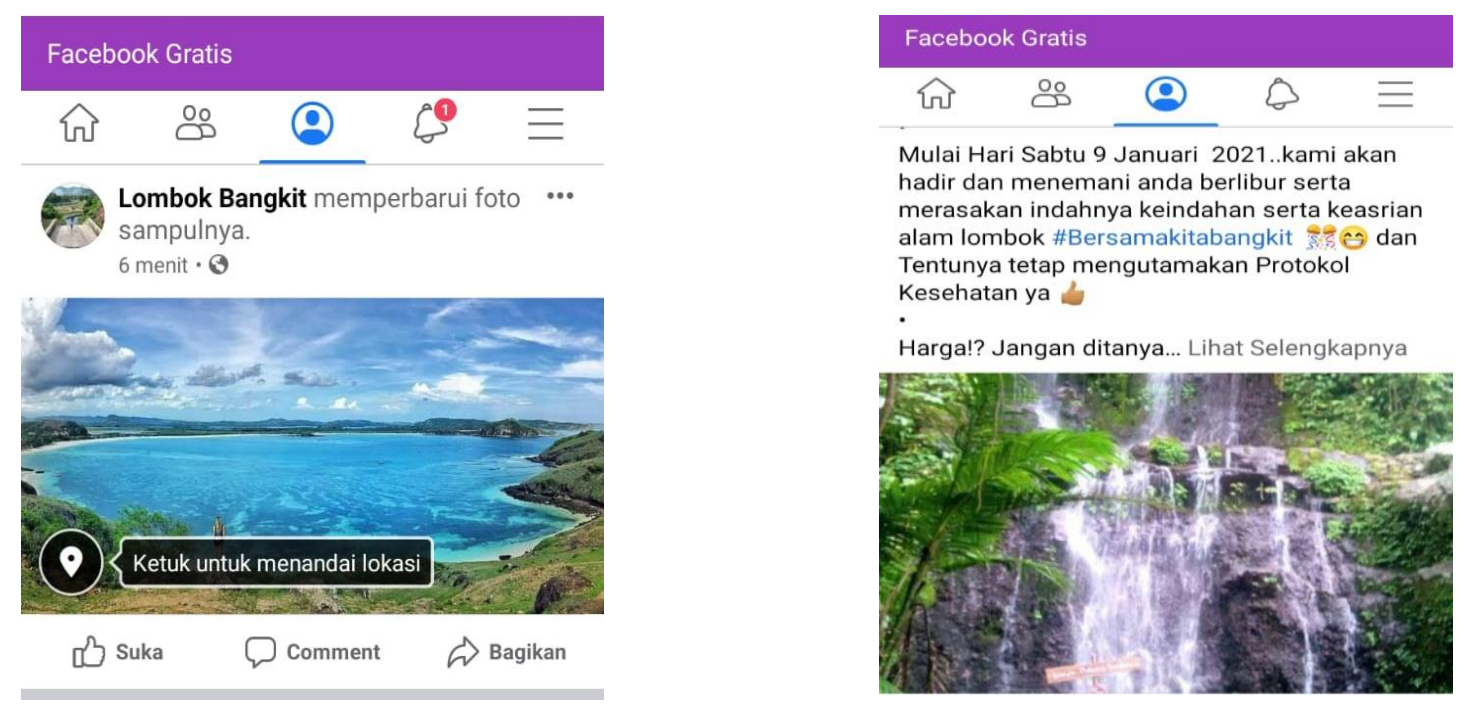

Gambar 4. Beberapa contoh hasil unggahan promosi peserta dengan akun facebook : a) Promosi keindahan wisata pantai di pantai Malimbu; b) promosi air terjun Benang Stokel Kabupaten Lombok Tengah 
Pada gambar diatas, terlihat bahwa pemanfaatan akun media social peserta dalam hal ini akun faceebook sudah mulai bisa dimanfaatkan untuk kegiatan promosi, dalam hal ini terlihat kegiatan promosi terkai dengan keindahan pantai yang ada di Pulau Lombok, serta keindahan air terjun yang ada. Secara konten yang ada, kegiatan pelatihan telah berhasil memberikan pemahaman dari peserta sehingga para peserta dapat membuat akun promosi wisata sesuai harapan yang ditargetkan dalam kegiatan ini. Adanya kegiatan promosi ini diharapkan dapat meningkatkan kembali minat wisatawan dating kembali berkunjung ke Pulau Lombok pasca pandemi yang ada. Kegiatan promosi lain juga dilakukan oleh peserta menggunakan akun media social lainnya, Berikut salah satu contoh unggahan dari peserta mengenai obyek wisata Pantai Kuta Lombok, Bukit erase dalam media sosial instagram (Gambar 5)
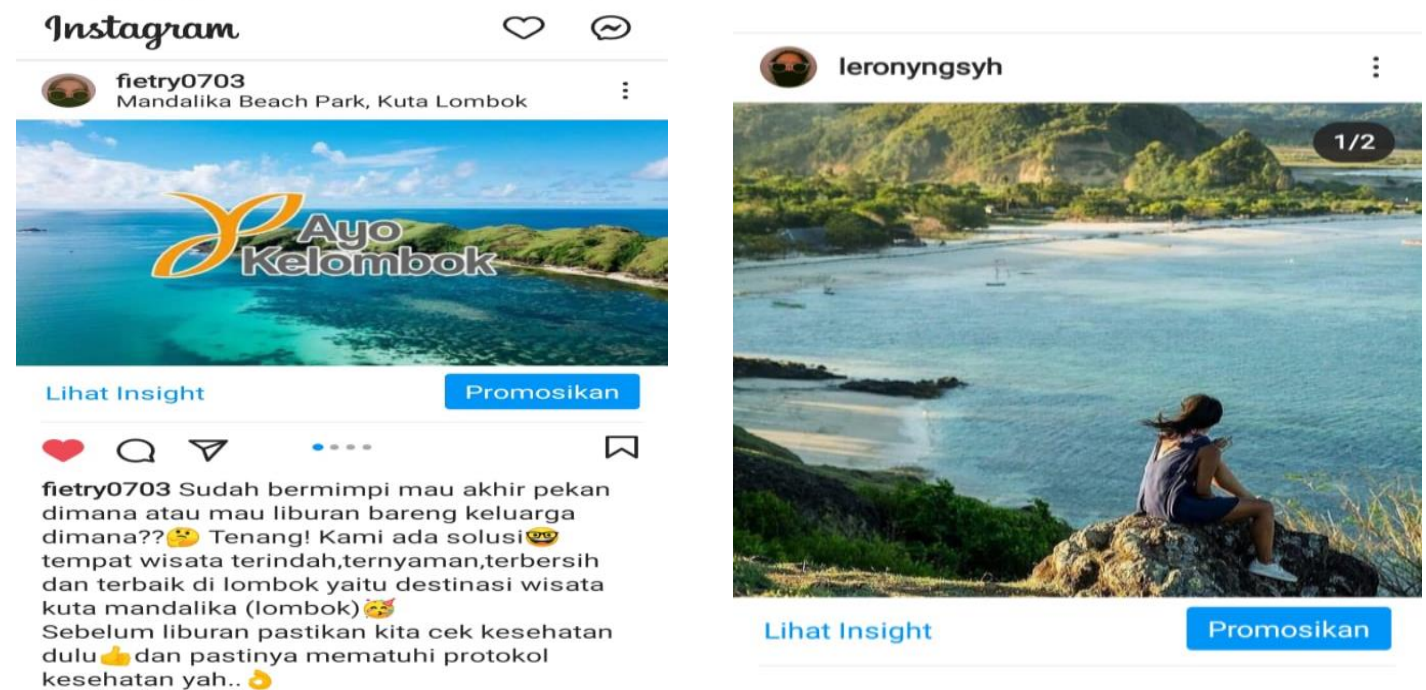

Gambar 5. Hasil unggahan Promosi peserta dengan akun Instagram : a) Promosi keindahan Pantai Kuta Lombok; b) Promosi Keindahan Bukit Merase Lommbok

Berdasarkan gambar diatas juga terlihat bahwa peserta yang berkunjung ke objekwisata mengunggah foto dan akun promosi mereka di media social instagram pribadi masing-masing, sehingga orang yang melihatpun juga berkemungkinan untuk berkunjung ke objek wisata tersebut. Dari kedua objek wisata tersebut terlihat bahwa dengan berkembangnya media sosial yang ditunjang dengan pengguna melalui partisipasi peserta pelatihan dalam mengunggah dan membagikan foto mereka ke dalam media sosial membuat kedua objek wisata tersebut dalam waktu singkat dapat dikenali dan menarik wisatawan untuk dating berkunjung dan membuat pengunjungnya menjadi meningkat.

\section{Evaluasi}

Monitoring dan evaluasi terhadap dampak pelatihan upaya peningkatan pengetahuan dan kapasitas skill pemanfaatan media social sebagai media promosi bertujuan untuk melihat secara langsung dampak dari kegiatan pelatihan yang sudah dilakukan. Dan terus melatih dan membiasakan peserta dalam membuat konten promosi sesuai tema dan target yang ingin diraih. Setelah kegiatan pelatihan ini dilakukan, maka selanjutnya proses monitoring dan evaluasi dilakukan untuk melihat keefektifan penerapan pelatihan ini. Dari hasil monitoring dan evaluasi ini, diperoleh saran bahwa dalam bermedia sosial, peserta mulai terbiasa menerapkan pemanfaatan media social untuk kegiatan promosi wisata. Hasil dari kegiatan ini adalah meningkatnya pengetahuan dan kemampuan peserta tentang pemanfaatan media social sebagai media promosi. 


\section{KESIMPULAN}

Berdasarkan hasil monitoring dan evaluasi pelatihan, pemanfaatan media social bagi media promosi bidang pariwisata. kegiatan pelatihan dapat berjalan dengan baik dan mendapat sambutan yang baik dari peserta pelatihan. Kegiatan ini dapat disimpulkan berhasil, mulai dari semua tahap pelaksanaan kegiatan yang diikuti peserta dengan adanya antusiasme dan respon positif peserta dalam mengikuti kegiatan pelatihan. Adanya kesesuaian materi dengan masalah yang dihadapi untuk meningkatkan pemahaman pemanfaatan media sosial, peserta pelatihan sudah dapat berinovasi atas manfaat dari akun media social yang dimiliki serta dapat memahami dan merasakan manfaat kegiatan pelatihan. Pada akhirnya, dampak dari kegiatan pelatihan ini secara praktis dapat meningkatkan pengetahuan dan skill peserta pelatihan di Madrasah Aliyah Al Madani Kabupaten Lombok Barat.

\section{PERNYATAAN}

Kegiatan pengabdian pada masyarakat ini dilaksanakan dengan menggunakan dana hibah institusi (LPPM, Universitas Universitas Pendidkan Mandalika Mataram). Oleh karena itu tim Pengabdi menyampaikan terima kasih yang sebesar-besarnya kepada Universitas Universitas Pendidkan Mandalika Mataram yang telah mendukung terlaksananya kegiatan pengabdian pada masyarakat ini.

\section{DAFTAR PUSTAKA}

Andi, Madcoms. 2010, Adobe Dreamweaver CS5 dengan Pemrograman PHP-MySQL. Penerbit. CV Andi Offset.

Agustina. (2016). Analisis penggunaan media sosial instagram terhadap sikap konsumerisme remaja di SMA Negeri 3 Samarinda. eJournal Ilmu Komunikasi, 4(3): 410-420.

Djalal, Fasli dan Supriadi, Dedi. 2001. Reformasi Pendidikan dalam Konteks Otonomi Daerah. Yogyakarta: Adicita

Faulkner, B. (2003). Tourism development options in Indonesia and the case of agro-tourism in central Java. In Embracing and Managing Change in Tourism (pp. 237-256). London: Routledge

Flew, Terry, (2002). New Media: An Introduc-tion. New York: Oxford Universi-ty Press.

Muttaqien,M dan Wardana,L.H. (2020). Pelatihan Jurnalisme Warga Sebagai Sarana Pengembangan Bakat Remaja dalam Dunia Digital Serta Promosi Wisata Desa Samiran Kecamatan Selo Kabupaten Boyolali. KACANEGARA Jurnal Pengabdian Masyarakat. Vol.3. No.2. Juli 2020.

Nasrullah, Rulli, (2018), Media Sosial Perspektif Komunikasi, Budaya, Dan Ssosioteknologi. Bandung: Simbiosa Rekatama Media.

Willie Wijaya. (2004). Kamus Lengkap Inggris-Indonesia.Semarang: Bintang Jaya.

Wilopo, K.H \& Hakim. L (2017). Startegi Pengembangan Destinasi Pariwisata Budaya (Studi Kasus pada Kawasan Situs Trowulan sebagai Pariwisata Budaya Unggulan di Kabupaten Mojokerto). Jurnal Administrasi Bisnis (JAB). Vol 41 No.1 .Januari 2017.

Wiro. (2018). Pengaruh Promosi Di Instagram Dan Word Of Mouth Terhadap Keputusan Berkunjung Di Pariwisata Puncak Mas Bandar Lampung (Thesis S2). Institut Informatika Dan Bisnis Darmajaya. http://repo.darmajaya.ac.id/402/3.

Zarella, D. (2010). The social media marketing book. Jakarta: PT Serambi Ilmu Semesta Anggota IKAPI. 